\title{
The Relations Between the Vitamins and Alzheimer Dementia
}

\author{
Emel Koseoglu \\ Erciyes University, Medicine Faculty, Neurology Department, Kayseri \\ Turkey
}

\section{Introduction}

The number of people suffering from dementia might triple over the next 50 years, measures for treatment and prevention of dementia are crucial. As vitamins are involved in many biochemical processes, they are essential for good health. They can possibly take role more probably in the prevention and treatment of dementia. For this reason, the relations between the vitamins and dementia, especially Alzheimer Dementia (AD) have been studied for many years.

Until the 1900s, vitamins were obtained solely through food intake, and changes in diet can alter the types and amounts of vitamins ingested. Vitamins have been produced as commodity chemicals and made widely available as inexpensive pills for several decades, allowing supplementation of dietary intake.

There are many observational studies indicating associations of vitamin deficiencies with cognitive dysfunction. Most of the studies in the subject are cross sectional studies. Nevertheless, these type of studies can not prove whether a nutritional deficit is the cause or the result of an impaired cognitive status. Longitudinal prospective observational studies and interventional studies are more suitable to releave causal relationships. Interventional studies with long follow up periods are preferred, since short follow up time can not be enough to evaluate the effects. There are some individual studies reporting promising, positive results about vitamin supplementation in prevention and treatment of dementia.

Vitamin A, C and E have antioxidant activity, which have been investigated for its prevention from neuronal death and improving neuronal function through maintaining mitochondrial homeostasis. Vitamin E may modulate signal transduction pathways and participate in the synthesis pathways of neurotransmitters. Several epidemiological studies have indicated a relationship between blood concentrations of antioxidant micronutrients and cognitive impairment. Though not sufficient, there are some prospective longitudinal and interventional studies indicating the useful effects of antioxidant vitamins in prevention and treatment of dementia.

Deficiencies of several B vitamins, including thiamine (B1), riboflavin (B2), niacin (B3), pyridoxine (B6), folate (B9) and cobalamin (B12) have been reported to be associated with cognitive dysfunction in many studies. In some studies, pathophysiological models have been formulated, including the association of $\mathrm{B}$ vitamin deficiencies with metabolic disturbances in the structural constituents of cerebral tissue, such as phospholipids and 
myelin, as well as in signaling molecules, such as neurotransmitters. More recently, the association between the deficiency of B vitamins, particularly folate and cobalamin, and cognitive impairment has been investigated in relation to hyperhomocysteinemia. It was shown that plasma homocysteine is a better correlate of cognitive function than the serum folate or cobalamin concentrations themselves. Homocysteine is a well established risk factor for vascular disease, but some epidemiological and cross sectional studies have also suggested that it may play a role in cognitive performance and pathophysiology of dementia in older people, possibly as the metabolic link between micro-vascular disease and Alzheimer dementia. Some prospective longitudinal and interventional studies have reported the useful effects of some B vitamins, though there existed contradictory results also. Furthermore, there was a large heterogenity among present vitamin B interventional studies with cognitive assessments in terms of dosage, routes of intervention (for vitamin B12), age and cognitive function assessments. It seems that it will be worthwhile to perform new larger studies, especially considering the results of the studies reporting recovering effect of folate supplementation on cognition.

The most recent reported vitamins related to cognitive functioning are vitamin $\mathrm{D}$ and vitamin K. Vitamin D has been reported to be critical to healthy brain development and function. Vitamin D in sufficient amounts seemed to protect brain cells and reduce inflammation according to some biological evidence. Some epidemiological and crosssectional studies showed the association of vitamin D deficiency with Alzheimer disease and dementia. To disclose if there is a causal relationship between them, prospective longitudinal studies are needed in the subject. Vitamin $\mathrm{K}$ is also required for normal brain development and function. Some authors proposed a possible role of vitamin K deficiency in the pathogenesis of Alzheimer disease. It is obviously useful to do experimental animal and case controlled human studies in the first step to clarify the role of vitamin $\mathrm{K}$ in the pathogenesis of dementia.

In this section, we will try to discuss the relations of AD with the antioxidant vitamins, B vitamins and lastly vitamin $\mathrm{D}$ and $\mathrm{K}$ with the help of cross-sectional or longitudinal prospective observational studies, and interventional studies. Nevertheless, the subject has many aspects. As vitamin deficiencies can cause cognitive impairment, cognitive impairment can also determine changes in dietary habits and consequently cause vitamin deficiencies. Vitamin intake through food or supplementation forms can have different effects. There is also a possibility that vitamins have useful effects in different subgroups of people, based on age, nutritional status or vitamin level. Multivitamin supplementation may be more useful. Detailed investigations about these aspects will be informative.

\section{Antioxidant vitamins}

\subsection{Pathophysiological mechanisms}

Brain tissue is particularly vulnerable to free-radical damage because of its low level of endogenous antioxidants (Reiter, 1995). Neuropathological studies documented typical lesions from exposure to free radicals in the brains of patients with AD (Behl, 1997; Christen, 2000; Pratico \& Delanty, 2000; Varadarajan et al., 2000). Lipid peroxidation seems to be especially susceptible to oxidative stress (Knopman, 1998; Pitchumoni et al., 1998; Sinclair et al., 1998). Increasing evidence also implicates neuronal membrane associated oxidative stress (for example, consequent to deposition of amyloid $\beta$-peptide $(\mathrm{A} \beta)$ ) and alteration of membrane lipid metabolism (and consequent accumulation of ceramides and cholesterol) as 
pathogenetic factors of synaptic dysfunction and neuronal degeneration (Cutler et al., 2004; Hyun et al., 2010; L.J. Miller \& Chacko, 2004). Antioxidant treatment improved neuronal function through maintaining mitochondrial homeostasis. In a canine model of human aging, it was shown that aged canine mitochondria showed significant increases in reactive oxygen species production and a reduction in NADH-linked respiration. Mitochondrial function was improved selectively in aged dogs treated with antioxidant diet (Head et al., 2009).

Vitamin A levels in brain decline with age and lower still in individuals with AD (Goodman, 2006).A metabolic product of vitamin A, retinoic acid, is known to slow cell death and offer protection from A $\beta$ (Sahin et al., 2005). In addition to its antioxidant activity, vitamin E may modulate signal transduction pathways and participate in the synthesis pathways of neurotransmitters (Azzi et al., 1992; Martin et al., 1997; Meydani et al., 1997). Plasma vitamin C level was decreased in AD in addition to vitamin A and E (Foy et al., 1999). Vitamin $C$ enhances the effect of medications used to treat dementia allowing the drugs to pass more easily into the brain and therefore to cause a greater effect. As a conflicting result, in the analysis of the association between the level of serum antioxidants and memory performance in an elderly, multiethnic sample of 4809 subjects; Perkins et al (Perkins et al., 1999) found a decreased serum level of vitamin E consistently associated with memory deficit after adjustment for age, education, income and vascular risk factors. Serum levels of other antioxidants (vitamins $\mathrm{A}$ and $\mathrm{C}, \beta$-carotene and selenium) did not correlate with memory performance.

\subsection{Studies}

SENECA study reported a positive, although weak, correlation between plasma concentrations of lycopene, $\alpha$ - carotene, $\beta$-carotene, total carotenes, $\beta$-cryptoxanthin, $\alpha$ tocopherol and Mini Mental State Examination (MMSE) scores (Haller et al., 1996). In the elderly population studied by Ortega et al., dietary intake of vitamin $C$, $\beta$-carotene and vitamin E were associated with a better cognitive function (Ortega et al., 2002). Perrig et al. (Perrig et al., 1997) showed that higher plasma ascorbic acid and $\beta$-carotene concentrations were associated with better memory performance in older people, both cross-sectionally and longitudinally over a 22 year period. In another cohort study performed on 455 elderly people with a duration of 7 year, high $\beta$-carotene levels were associated with less cognitive decline in APOE4 carriers but not in APOE4 negatives (Hu et al., 2006). Rats given dietary supplements of fruit and vegetable extracts for 8 months, beginning at 6 months of age, slowed age-related declines in neuronal and cognitive functions (Joseph et al., 1998). More importantly, these rats were able to reverse age-related deficits in several neuronal and behavioral parameters when administration was started at 19 months of age (Joseph et al., 1999). In another study investigating the effects of acute, short and long term pre-training administration of ascorbic acid on passive avoidance learning and memory in rats, it was concluded that short- and long-term supplementation with ascorbic acid (vitamin C) had facilitatory effects on acquisition and retrieval processes of passive avoidance learning and memory in rats (Shadidi et al., 2008).

Vitamin C supplements were shown to protect against cognitive decline in a 4 year follow up study (Paleologos et al., 1998). In Rotterdam Study (Engelhart et al., 2002), the cohort study of dietary antioxidants with a duration of 6 years, high intakes of vitamin $\mathrm{C}$ and $\mathrm{E}$ were found to be associated with lower risk of AD. In a recent study on 5395 participants 
older than 54 years of age and free of dementia with a mean follow up period of 9.6 years, it was shown that participants in the highest tertile of vitamin E intake were $25 \%$ less likely to develop dementia compared with those in the lowest tertile of the intake. Dietary intake levels of vitamin C, beta carotene, and flavonoids were not related with dementia risk after multivariate adjustments. Results were similar when risk for AD was specifically assessed (Devore et al., 2010). In CHAP cohort study, on 815 elderly residents free of AD at baseline with a follow up period of 3.9 years, it was found that dietary vitamin $E$ was associated with decreased risk for $\mathrm{AD}$, while intakes of vitamin $\mathrm{C}, \beta$-carotene and vitamin $\mathrm{E}$ from supplements were not associated at all (M.C. Morris et al., 2002). In another study investigating the effects of high dietary intake of vitamin $\mathrm{E}$ on prevention from $\mathrm{AD}$, it was found that a-tocopherol alone may not be as protective as the combined tocopherols (M.C. Morris et al., 2005a). In addition, the risk of AD was inversely related to the intake of $a, y$ and $\delta$ but not $\beta$ tocopherol. It was found that higher levels of dietary vitamin E lowered the risk of $\mathrm{AD}$ and slowed cognitive decline over the six-year course of the investigation.

In Cache County study, performed on 3227 subjects older than 64 years of age with a followup period of 3 years, vitamin $\mathrm{E}$ and $\mathrm{C}$ supplements in combination were associated with reduction in $\mathrm{AD}$ incidence, but not in users of those supplements alone (Zandii et al., 2004). Likewise, in another cohort study with a 5 year follow-up period, conducted on 894 elderly subjects, combined use of vitamins $E$ and $C$ supplements were associated with less cognitive decline (Maxwell et al., 2005); while in another study performed on 2969 elderly participants without cognitive impairment at baseline, the use of supplemental vitamin E and C, alone or in combination, did not reduce risk of AD or overall dementia over 5.5 years of follow-up period (Gray et al., 2008). In spite of the successful results of dietary intake of vitamin $\mathrm{E}$ on the prevention, supplemental use of it alone (2000 IU/day) was not shown to have an effect on progression of minimal cognitive impairment to $\mathrm{AD}$ and on mean cognitive change in randomised controlled studies respectively (Kang et al., 2006; Petersen et al., 2005). In a randomised controlled study performed on 341 patients with moderate $\mathrm{AD}$, the patients treated with selegiline, a-tocopherol supplement or combination of them had longer time to institutionalization (Sano et al., 1997). However, no significant benefit was shown in cognitive tests.

About the role of vitamin $\mathrm{E}$ in treatment, there is a safety problem other than analying its effectiveness. Recent meta-analyses of randomized trials involving vitamin $\mathrm{E}$ in cardiac patients and other patient groups suggest a slightly higher mortality risk associated with vitamin E treatment (Bjelokovic et al., 2007; E.R. Miller et al., 2005; Vivekananthan et al., 2003). One meta -analysis (E.R. Miller, 2005) concluded that the mortality rate associated with vitamin $\mathrm{E}$ treatment increased in a nonlinear dose-dependent manner, with the relative risk beginning to rise above 1 at doses $\geq 400 \mathrm{IU} /$ day. In a study about this subject performed on 847 probable or mixed AD patients with a follow up period up to 15 years, there was no evidence that treatment with high doses of vitamin E (2000 IU/day)had an adverse effect on survival. In fact, patients whose regimens included vitamin E tended to survive longer than those taking no drug or a choline esterase inhibitor alone. It is noteworthy that the survival benefit to those taking vitamin E did not become apparent until after 4 or more years of follow up. In light of the potential for beneficial effects on vitamin $\mathrm{E}$ and mixed clinical trial evidence, these results emphasize the need for additional research on vitamin E supplementation in AD using a dose range that extends above 400 IU per day. 


\subsection{Comments}

In conclusion, there are positive results about the use of antioxidant vitamins on mostly prevention of $\mathrm{AD}$ and mostly through diet. There is not sufficient evidence about their use in the treatment. In recent years, it seems that the researches on vitamin $E$ and $C$ have dominated. This can be due to the relation of these vitamins to the structure and physiology of brain and, more consistent finding of association between serum levels of vitamin $\mathrm{E}$ and memory performance in the studies. However, vitamin A is also a good candidate for more future studies.

The intake of vitamins through diet or supplementation forms and the number or quantity of different vitamins and presence of other ingredients in the supplementation forms can change the effect. For example, in the manufactured capsules of vitamin E, only atocopherol is present. But at real, vitamin $\mathrm{E}$ is composed of 4 different tocopherol forms and 4 corresponding tocotrienols. This may cause ineffectiveness of vitamin E supplementation found in some studies. Also, the interaction of antioxidant vitamins with other antioxidants like flavonoids and other chemicals present in fruits and vegetables can provide benefit in the dietary intake of vitamins.

\section{B vitamins}

\subsection{Pathophysiological mechanisms}

Deficiencies of several B vitamins, including thiamine (B1), riboflavin (B2), niasin (B3), pyridoxine (B6), folate (B9) and cobalamin (B12), have been related with cognitive dysfunction in many observational study (Riedel et al., 1998). In some studies, pathophysiological models have been formulated, including the association of B vitamin deficiencies with metabolic disturbances in the structural constituents of cerebral tissue, such as phospholipids and myelin, as well as in signaling molecules, such as neurotransmitters (Rampersaud et al., 2003). In particular, thiamine deficiency has been associated with lactic acid accumulation, reduction in oxygen uptake, decrease in transketolase activity, and an impairment in cholinergic activity, leading to the loss of memory and other cognitive functions (Micheau et al., 1985). Cobalamin is essential for neuronal generation and its deficiency can cause degeneration of the nervous system (Herrmann \& Obeid, 2007). Various cobalamines were shown to have intracellular antioxidant activity in vitro. The compounds inhibited intracellular peroxide production, maintained intracellular glutathione levels, and prevented apoptotic and necrotic cell death (Birch et al., 2009). Folic acid plays an important role in neuroplasticity and in the maintenance of neuronal integrity (Kronenberg et al., 2009). It enhances the plasma concentrations of docosahexaenoic acid (DHA) and eicosapentaenoic acid (EPA). EPA, DHA, and arachidonic acid are of benefit in dementia by up-regulating gene expression concerned with neurogenesis, neurotransmission and connectivity, improving endothelial nitric oxide (eNO) generation, enhancing brain acetylcholine levels, suppressing the production of proinflammatory cytokines and precursing to anti-inflammatory compounds that protect neurons from cytotoxic action of various noxious stimuli, oxidative stress and neuronal apoptosis (Das, 2008).

Recently, the association between the deficiency of B vitamins, particularly folate and cobalamin, and cognitive impairment has been investigated in relation to hyperhomocysteinemia (hHcy). Several epidemiological studies have also suggested that hHcy may play a role in the cognitive performance (Prins ND, 2002) and pathophysiology of 
dementia in older people (Bell et al, 1992; Nilsson et al., 1996; Wahlin et al., 1996), possibly as the metabolic link between micro-vascular disease and old-age dementia (M.S. Morris et al., 2001; Parnetti et al., 1997). Feeding mice with a B-vitamin deficient diet for 10 weeks induced hHcy, significantly impaired learning and memory, and caused a significant rarefaction of hippocampal microvasculature unrelated to gliosis and neurodegeneration (Troen et al., 2008).

Homocystein (Hcy) is an aminoacid entirely derived from the body's intermediary metabolism (Fekkes et al., 1998; Pietrzik \& Bronstrup, 1997), which can be converted to either methionine or cysteine. Both folate and cobalamin participate in the methylation of Hcy to methionine and in the remethylation and synthesis of S-adenosylmethionine (Bottiglieri, 1996; Parnetti et al., 1997). The other metabolic pathway, which converts Hcy to cysteine requires the active form of vitamin B6 (pyridoxal phosphate) (Pietrzik \& Bronstrup, 1997). The most common cause of hHcy is accepted to be a deficiency of folate or cobalamin (Selhub, 2000). Almost two-thirds of the prevalance of hHcy is attributable to low vitamin B status or intake (Selhub J, 2008). Although the catabolic rate of Hcy results from the interaction between genetic make-up and B vitamin status, it is generally accepted that elevated plasma Hcy concentrations are a sensitive marker for folate and cobalamin tissue deficiency (Bottiglieri, 1996; Joosten et al., 1993; Lokk, 2003; McCaddon et al., 1998; Nilsson et al., 1996; Nilsson et al., 1999; Parnetti et al., 1997).

Folate and vitamin B12 are essential cofactors for the methionine/Hcy cycle in the brain. These vitamins mediate the remethylation of Hcy, which affects the production of the universal methyl donor, S-adenosylmethionine, in the brain among other organs. Hypomethylation, caused by low B-vitamin and hHcy, is linked to key pathomechanisms of dementia (Obeid et al., 2007). Also, Hcy is recognised to be proatherogenic and protrombotic (Hassan et al., 2004) and accepted to be an independent risk for developing occlusive arterial diseases (Refsum et al., 1998; Ueland \& Refsum, 1989). hHcy exerts an inhibitory effect on adult mouse brain neurogenesis (Rabaneda et al., 2008). Low folate status and elevated Hcy increase the generation of reactive oxygen species and contribute to excitotoxicity and mitochondrial dysfunction which may lead to apoptosis (Kronenberg et al., 2009). hHcy is also proposed to be one of the effects of the oxidation of vitamin B12, as a result of oxidative stress (McCaddon et al., 2002). Furthermore, experimental studies in cell cultures have shown that Hcy is neurotoxic, possibly by activating N-methyl-D-aspartate receptors (Lipton et al., 1997) or DNA damage and consequent apoptosis (Kruman et al., 2000). In a population based study on 1779 subjects, hHcy has been reported to be an independent risk factor for dementia and cognitive impairment without dementia (Haan et al., 2007).

Depending on the used marker, 3-60\% of the elderly are classified as vitamin B12 deficient and about $29 \%$ as folate deficient. Predominantly, the high prevalance of poor cobalamin status is caused by the increasing prevalance of atrophic gastritis type B, which occurs with a frequency of approximately $20-50 \%$ in elderly subjects (Wolters et al., 2004). Another cause of atropfic gastritis is long term treatment with proton pump inhibitors (Kuipers et al., 1995,1996; Lundell et al., 2006). Atrophic gastritis results in declining gastric acid and pepsinogen secretion, and hence decreasing intestinal digestion and absorption of both B vitamins. Such patients with atrophic gastritis require parenteral supplements. Folic acid intake among elderly subjects is generally well below the recommended dietary reference values (Wolters et al., 2004). So, folic acid deficiency is primarily caused by dietary deficiency. Meanwhile, vitamin B12 deficiency is due to two main causes, food cobalamin malabsorption and pernicious anemia (Andres et al., 2004). 


\subsection{Studies}

Many epidemiological, cross-sectional and case control studies reported the association of dementia with low blood levels of vitamin B12 and folate or hHcy. Hovewer, these studies are unable to exclude the possibility that such associations of hHcy or vitamin B deficiencies are rather a result than a cause of the disease.

Kivipelto $\mathrm{M}$ et al (Kivipelto et al., 2009), in their prospective study found that persons with high Hcy had more than twice as high a risk of developing AD than persons with low Hcy, even after adjusting for confounding or mediating factors, suggesting that Hcy is involved in the development of dementia and AD. Vitamin B12 itself seemed not to be directly involved, because holo-transcobalamin showed no association with dementia. In some cohort studies, hHcy was found to be correlated with decline in constructional praxis and recall memory (Tucker et al., 2005) and increased risk for dementia (Dufoil et al., 2003; Haan et al., 2007; Ravaglia et al., 2005; Seshadri et al., 2002; McCaddon et al., 2001), while in some others it was not correlated with cognitive decline (Clarke et al., 2007; Kalmijn et al., 1999; Luchsinger et al., 2004; Mooijaart et al., 2005; Teunissen et al., 2003). In the cohort studies, low plasma level of folate was found to be associated with decline in constructional praxis and lower cognitive function regardless of Hcy respectively (de Lau et al., 2007; Tucker et al., 2005). In another cohort study performed on 370 non demented persons older than 74 years of age, persons with low serum level of vitamin B12 or folate had the risk of developing AD (Wang et al., 2001). In addition to low folate and high Hcy plasma levels, low plasma concentration of vitamin B12 was also associated with decline of constructional praxis in a 3 year cohort study (Tucker et al., 2005).

Cohort studies of dietary intake of B vitamins in healthy elderly persons revealed conflicting results. In one of them, dietary intake was found to be not related with the risk of developing AD (MC Morris, 2006a). In another, the highest quartile of total folate intake was related to lower risk of AD (Luchsinger et al., 2007), while the other reported that rate of cognitive decline among persons in the top folate intake was more than twice that of those in the lowest fifth of intake (MC Morris et al., 2005b).

Despite potential benefits of vitamin B supplementation for lowering Hcy, the positive contribution of this supplementation to cognitive function among demented and nondemented persons remains debatable. There was a large heterogeneity among present vitamin B interventional studies with cognitive assessments in terms of dosage, routes of intervention (for vitamin B12), age and cognitive function assessments.

It has been proven that folate supplementation reduces plasma Hcy levels. This was observed by Jacques et al. in the Framingham Offspring Study cohort, after the folate fortification of grain in the Unites States started in January 1998 (Jacques et al., 1999). Nevertheless, the relationship between dietary folic acid intakes and plasma Hcy concentrations seems to be characterized by a threshold effect (Selhub, 1993): above a certain dosage of folate supplementation, there is no additional effect on lowering circulating Hcy. It is not clear where this threshold stands: a metanalysis of 12 randomized controlled trials assessed that the minimum dosage of folate capable of determining a maximum reduction (about \%25) of circulating Hcy was $0.5 \mathrm{mg}$ / day. More recent randomized trials determined this threshold at $0.8 \mathrm{mg} /$ day (Wald et al., 2001) or $0.4 \mathrm{mg} /$ day (van Oort et al., 2003). The differences are possibly explained by population selection biases (van Oort et al., 2003).

Some randomised controlled trials, including persons with normal cognitive function, cognitive impairment and dementia, evaluated the effect of folate supplementation on cognitive function. Among cognitively impaired subjects $(n=30)$ with low folate serum 
levels, Fioravanti et al (Fioravanti et al., 1998) observed a significant improvement of some scores of the Randt Memory Test in the folate treated group compared with the placebo group after 60 days of treatment. In another trial using a mixed factorial design in normal subjects $(n=211)$, the authors observed that folate-treated older women's cognitive test scores (Rey Auditory-Verbal Learning Test) improved (Bryan et al., 2002). Controversially, in another small study including 7 subjects with dementia reported no statistically significant differences between the supplemented group and the control group, and noted a negative trend in specific test scores of the supplemented group (Sommer et al., 2003). Because of the small number of subjects, study results need to be interpreted cautiously. Finally, the 3-year randomised controlled FACIT trial included 818 older subjects (older than 60 years) with augmented plasma total Hcy and normal serum vitamin B12 levels. The effect of folic acid supplementation on cognition was the secondary end point. The 3-year change in memory, information processing speed and sensorimotor speed were significantly improved in the folic acid group in comparison to the placebo group (Durga et al., 2007). Folic acid potentiated the effect of memantine on spatial learning and neuronal protection in an AD transgenic model (Chen et al., 2010).

Some other randomised controlled studies assessed the effect of vitamin B12 intervention on cognitive functions in humans. There is a large heterogeneity among trials regarding the cognitive status of participants, the doses and administration routes of vitamin B12, the duration of supplementation and the applied cognitive function assessment instruments. Sample sizes ranged from 18 to 78 subjects receiving vitamin B12, and the duration of supplementation ranged from 4 weeks to 6 months. For most cognitive tests, there was no significant improvement in vitamin B12 supplemented patients as compared with the placebo group (Eussen et al., 2006; Hvas et al., 2004; Stoot et al., 2008). However, Bryan J et al found that healthy younger, middle-aged and older women $(n=211)$ who took vitamin B12 (or either of folate and vitamin B6 ) for 35 days showed better performance on some measures of memory performance compared to placebo (Bryan et al., 2002). Interestingly, a statistically significant worsening of cognitive tests was reported in two studies. In 195 vitamin B12 deficient subjects of normal and impaired cognition, Eussen et al (Eussen et al., 2006) observed that improvement of the cognitive test score in the placebo group was significantly more marked than that of the vitamin B12 group. Similarly, another study reported a significant worsening of the ' 12 words learning test' score in a vitamin B12 treated population of 140 old patients with cognitive impairment and methylmalonic acidemia, in comparison to the placebo group (Hvas et al., 2004). For reasons of heterogeneity of these controlled trials, no reasonable conclusion can be drawn regarding the effects of vitamin B12 on cognition. In addition, several uncontrolled cohort studies assessed the effects of vitamin B12 intervention on cognitive function in humans with conflicting results.

A few studies (Lewerin et al., 2005; McMahon et al., 2006; Stott et al., 2005; van Uffelen et al., 2007) reported data of combined B vitamin intervention on cognition, in subjects with normal cognition, dementia or vascular disease (17-409 participants). Trial durations ranged from 12 weeks to 2 years. One study found a significant improvement in one of eight cognitive tests (Reitan trail-making test, part B) (McMahon et al., 2006). In a recent randomized, double-blind controlled study in 271 individuals over 70 years old with mild cognitive deficit, high dose B vitamins lowering Hcy level slowed the rate of accelerated brain atrophy, which was found to be major determinant of cognitive decline in this population (Smith et al., 2010). It was reported that trials were needed to see if the same treatment will delay the development of AD (Smith et al., 2010). 


\subsection{Comments}

Most studies reporting associations between cognitive function and Hcy or B vitamins have used a cross-sectional or case-control design and have been unable to exclude the possibility that such associations are a result of the disease rather than being causal. The prospective study indicating that persons with high Hcy have more than twice as high as developing AD than persons with low Hcy, even after adjusting for confounding or mediating factors, is an important one. The Hcy hypothesis of dementia has attracted considerable interest, as Hcy can be easily lowered by folic acid and vitamin B12, raising the prospect that B-vitamin supplementation could lower the risk of dementia (Clarke et al., 2008). While some trials assessing effects on cognitive function have used folic acid alone, vitamin B12 alone or a combination, few trials have included a sufficient number of participants to provide reliable evidence. Among these studies, FACIT Trial (Durga et al., 2007) is an outstanding one. This large, randomised and controlled trial on elderly participants with high plasma Hcy and normal vitamin B12 serum level have showed that folic acid supplementation improved several cognitive domains that tend to decline with advancing age. Therefore, folate supplementation may be an interesting approach to prevent cognitive decline in elderly people. New trials with larger number of participants are needed to test the importance of vitamin B intake through diet or supplementation forms in the prevention and treatment of AD.

\section{Vitamin D}

Vitamin D exhibits functional attributes that may prove neuroprotective through antioxidative mechanisms, neuronal calcium regulation, immunomodulation, enhanced nerve conduction and detoxification mechanisms. Compelling evidence supports a beneficial role for the active form of vitamin $\mathrm{D}$ in developing brain as well as in adult brain function. The vitamin D receptor and, biosynthetic and degredative pathways for the hydroxylation of vitamin $\mathrm{D}$ have been found in the rodent brain; more recently these findings have been confirmed in humans. The vitamin D receptor and catalytic enzymes are colocalized in the areas of the brain involved in complex planning, processing, and the formation of new memories. These findings potentially implicate vitamin $\mathrm{D}$ in neurocognitive function (Buell \& Dawson-Hughes, 2008).

Treatment with $1,25(\mathrm{OH})_{2} \mathrm{D}_{3}$ attenuated hippocampal atrophy and protected neuron density ( a marker for neuronal death) in aging rats (Landfield \& Cadwalleder-Neal, 1998). Data in human subjects with AD revealed a reduction in VDR mRNA in specific regions of the hippocampus (CA1 and CA2) compared to controls (Sutherland et al., 1992) and a higher frequency of VDR polymorphisms were found in Alzheimer's brains than age-matched controls (Gezen-Ak et al., 2007).

Low serum levels of $25(\mathrm{OH}) \mathrm{D}$ have been associated with increased risk for cardiovascular diseases, diabetes mellitus, depression, dental caries, osteoporosis, and periodontal disease, all of which are either considered risk factors for dementia or have preceded incidence of dementia. There is a higher prevalence of falls and fractures in patients with AD (Buchner \& Larson, 1987) and community studies have shown that residents with AD and dementia had lower serum concentrations of 25(OH)D (Kipen et al., 1995). While the temporal associations of these findings remains unclear, in a study in patients with $\mathrm{AD}, 25(\mathrm{OH}) \mathrm{D}$ concentrations were significantly elevated after year-round sun exposure. Additionally, the sun- exposed cohort had a reduced risk of falls and fractures compared to the unexposed (Sato et al., 2005). 
Data from the Nutrition and Memory in Elderly study (NAME) (Scott et al., 2004) supported these findings. In subjects $(n=318)$ who completed a full neurological and psychiatric examination, in addition to magnetic resonance imaging, it was observed that vitamin $\mathrm{D}$ concentrations were lower in patients with dementia than those without. Additionally, vitamin D concentrations lesser than $50 \mathrm{nmol} / \mathrm{L}$ were associated with a higher prevalence of a diagnosis of possible or probable $\mathrm{AD}$. In a recent cross-sectional investigation of vitamin $\mathrm{D}$, dementia and MRI measures of cerebrovascular disease among 318 participants, mean vitamin $\mathrm{D}$ concentrations were lower in subjects with dementia. There was a higher prevalence of dementia, large vessel infarcts and increased white matter hyperintensity volume among participants with vitamin D insufficiency. After adjustment for age, race, sex, bodymass index, and education, vitamin D insufficiency was associated with more than twice the odds of all cause dementia, AD and stroke (Buell et al., 2010). Based on increasing number of studies linking the risk factors of $\mathrm{AD}$ with vitamin D deficiency, Grant WB (Grant, 2009) states that there are established criteria for causality in a biological system. The important criteria include strength of association, consistency of findings, determination of the dose-response relation, an understanding of the mechanisms, and experimental verification. Grant WB (Grant, 2009) suggests that further investigation of possible direct or indirect linkages between vitamin D and dementia is needed. Studies of incidence of dementia with respect to prediagnostic serum $25(\mathrm{OH}) \mathrm{D}$ or of vitamin D supplementation are warranted. In addition, since the elderly are generally vitamin $\mathrm{D}$ deficient and since vitamin $\mathrm{D}$ has so many health benefits, those over the age of 60 years should consider having their serum $25(\mathrm{OH}) \mathrm{D}$ tested, looking for a level of at least $30 \mathrm{ng} / \mathrm{ml}$ but preferably over $40 \mathrm{ng} / \mathrm{ml}$, and supplementing with 1000-2000 IU/day of vitamin D3 or increased time in the sun spring, summer, and fall if below those values (Grant, 2009).

\section{Vitamin K}

Vitamin $\mathrm{K}$ is necessary for the liver functioning. Vitamin $\mathrm{K}$ dependent $\mathrm{\gamma}$-carboxylation of glutamate takes part in formation of the coagulation factors 2, 7, 9 and 10. More recently, it has been established that vitamin $\mathrm{K}$ dependent $\gamma$-carboxylation of glutamate occurs also in extrahepatic sites and modifies proteins with other functions. One of these sites is brain. Allison AC (Allison, 2001) proposed a possible role of vitamin $\mathrm{K}$ deficiency in the pathogenesis of $\mathrm{AD}$ and in augmenting brain damage associated with cerebrovascular disease, based on the potential actions of vitamin $\mathrm{K}$ in the brain and through a link to the apolipoprotein $\mathrm{E}$ genotype. The apolipoprotein $\mathrm{E} 4$ allele, an established risk factor for $\mathrm{AD}$ (Mattson, 2004), strongly influences plasma vitamin K levels (Kohlmeier M, 1996; Saupe J, 1993). Thus, carriers of apolipoprotein $\mathrm{E} 4$ allele could also those with the lowest vitamin $\mathrm{K}$ concentrations, an association that has not yet been investigated. Vitamin $\mathrm{K}$ is required for normal brain development and function. The maternal exposure to coumarin derivatives is associated with abnormalities of the central nervous system (Pauli \& Haun, 1979). Vitamin K deficiency is associated with decrased sulfation in the brain. Keratan sulfate is dramatically decreased in cerebral cortex of AD patients (Lindahl, 1996). Considering keratan sulfate proteoglycan being the major protein of synaptic vesicles (Scranton et al., 1993), one manifestation of decreased sulfation can be abnormal structure and function of the major protein of synaptic vesicles (Allison, 2001). Likewise, addition of vitamin $\mathrm{K}$ to the chick embriyo increases tyrosine phosphorylation in the brain adhesion and cytoskletal proteins (Saxena et al., 1997), suggesting that vitamin K plays an role in the development of the 
central nervous system. Another vitamin $\mathrm{K}$ dependent protein in the brain is Gas 6, a product of growth arrest specific gene 6 . Both Gas 6 and its tyrosine kinase receptor are widely distributed throughout the central nervous system (Prieto et al., 1999). Interaction of these plays an important role in preventing neurons from apoptosis (Allen et al., 1999). Cell culture studies have shown that Gas 6 can rescue cortical neurons from $A \beta$ induced apoptosis (Yagami et al., 2002) and provided evidence that vitamin $\mathrm{K}$ can have a protective role against oxidative injury in developing oligodendrocytes and neurons (Denisova \& Booth, 2005).

Considering that a relative deficiency of vitamin $\mathrm{K}$, affecting the extrahepatic functions of the vitamin, is common in aging men and women; Allison AC (Allison, 2001) suggests that it is obviously useful to do experimental animal and case controlled human studies in the first step to clarify the role of vitamin $\mathrm{K}$ in the pathogenesis of dementia. In a likely study, low vitamin $\mathrm{K}$ intakes in 31 community-dwelling elders at an early stage of AD was detected in comparison to 31 age and sex matched cognitively intact control subjects (Presse et al., 2008).

\section{Multi-intervention}

Due to the fact that the interventional trials with antioxidants and B-vitamins did not hold the expectations, studies combining micronutriens are of particular interest. To date, a few prospective studies estimating the effect of nutrition and vitamin supplementation exist. One of these studies (Wolters et al., 2005) was performed on 220 healthy, free living women older than 60 years of age. After taking multivitamins (containing 8 vitamins and 4 minerals) for 6 months daily, no change on cognitive performance was observed as compared to placebo. The intervention period of only 6 months may be too short for improving cognitive performance in well-educated elderly women without dementia. Another study (McNeill et al., 2007) was performed on 910 healthy men and women aged 65 years and over. Four hundred and fifty six of them were on active daily treatment with 11 vitamins and 5 minerals for 12 months, while the remaining ones took placebo. Benefit was detected only on verbal fluency tests in the subgroups of participants aged over 74 years or those with increased risk of micronutrient deficiency. In a 12 month, open label trial with 14 mild AD patients, the efficacy of a multi-component formulation showed promising results regarding neuropsychiatric inventory and activities of daily living (Chan et al., 2008). This was confirmed by placebo-controlled data from 12 institutionalized patients with moderate to severe AD showing improvement in cognition, mood, and daily function (Remington et al., 2009). As a result, to draw any conclusion, larger randomized controlled studies with combined supplements are needed, especially in the context that multi-component dietary approaches such as Mediterranean diet or fruit and vegetable (or juice) consumption have been shown to be successful (Barberger-Gateau et al, 2007; Dai et al., 2006; MC Morris et al., 2006b; Scarmeas et al., 2006, 2009).

\section{Conclusion}

There is a relationship of levels of antioxidant vitamins and B vitamins to vascular dementia. Nevertheless, if this relationship is based on causality, it is not so clear after performed longitudinal and interventional studies. New trials with larger number of participants will be more clarifying. Recently, vitamin D deficiency has been found to be related with AD. Longitudinal and interventional studies, especially with long follow up 
period, will be informative about its role. Additionally, vitamin $\mathrm{K}$ is thought to have a possible role in the pathogenesis of dementia.

The subject has multiple aspects. As vitamin deficiencies can cause cognitive impairment, cognitive impairment can also determine changes in dietary habits and consequently cause vitamin deficiencies. Vitamin intake through diet or supplementation forms can have different effects. There is also a possibility that vitamins have useful effects in different subgroups of people, based on age, nutritional status or vitamin level. Multivitamin supplementation may be more useful. The roles of vitamins in dementia are not clear yet as those of macronutrients in spite of the reports expressing the benefits of caloric restriction and intake of higher unsaturated fatty acids on cognitive functions. Presence of relationships between macronutrients and vitamins is also possible. Detailed investigations about these aspects will be informative.

\section{References}

Allen MP, Zeng C, Schneider K, Xiong X, Meintzer MK, Bellosta P, Basilico C, Varnum B, Heidenreich KA \& Wierman ME. (1999). Growth arrest-specific gene 6 (gas6)/adhesion related kinase (Ark) signaling promotes gonadotropin-releasing hormone neuronal survival via extracellular signal related kinase (ERK) and Akt. Mol Endocrinol, Vol.13, No.2, (February 1999), pp. 191-201, ISSN 0888-8809.

Allison AC. (2001). The possible role of vitamin K deficiency in the pathogenesis of Alzheimer's disease and in augmenting brain damage associated with cardiovascular disease. Medical Hypothesis, Vol.57, No.2, (August 2001), pp. 151-5, ISSN 0306-9877.

Andres E, Loukili NH, Noel E, Kaltenbach G, Abdelgheni MB, Perrin AE, Noblet-Dick M, Maloisel F, Schlienger JL \& Blickle JF. (2004). Vitamin B12 (cobalamin) deficiency in elderly patients. CMAJ, Vol.171, No.3, (August 2004), pp. 251-9, ISSN 0820-3946.

Azzi A, Boscoboinik D \& Hensey C. (1992). The protein kinase C family. Eur J Biochem, Vol.208, No.3, (September 1992), pp. 547-57, ISSN 0014-2956.

Barberger-Gateau P, Raffaitin C, Letenneur L, Berr C, Tzourio C, Dartigues JF \& Alperovitch A. (2007). Dietary patterns and risk of dementia: the three-city cohort study. Neurology, Vol.69, No.20, (November 2007), pp. 1921-30, ISSN 0028-3878.

Behl C. (1997). Amyloid beta-protein toxicity and oxidative stres in Alzheimer's disease. Cell Tissue Res, Vol.290, No.3, (December 1997), pp. 471-80, ISSN 0302-766X.

Bell IR, Edman JS, Selhub J, Morrow FD, Marby DW, Kayne HL \& Cole JO. (1992). Plasma homocysteine in vascular disease and in non-vascular dementia of depressed elderly people. Acta Psychiatr Scand, Vol.86, No.5, (November 1992), pp. 386-90, ISSN 0001-690X.

Birch CS, Brach NE, McCaddon A \& Williams JH. (2009). A novel role for vitamin B(12): Cobalamins are intracellular antioxidants in vitro. Free Radic Biol Med, Vol.47, No.2, (July 2009), pp.184-8, ISSN 0891-5849.

Bjelakovic G, Nikolova D, Gluud LL, Simonetti RG \& Gluud C. (2007). Mortality in randomized trials of antioxidant supplements for primary and secondary prevention: systematic review and meta-analysis. JAMA, Vol.297, No.8, (February 2007), pp. 842-57, ISSN 0098-7484.

Bottiglieri T. (1996). Folate, vitamin B12, and neuropsychiatric disorders. Nutr Rev, Vol.54, No.12, (December 1996), pp. 382-90, ISSN 0029-6643. 
Bryan J, Calvaresi E \& Hughes D. (2002). Short-term folate, vitamin B-12 or vitamin B-6 supplementation slightly affects memory performance but not mood in women of various ages. J Nutr, Vol.132, No.6, (June 2002), pp. 1345-56, ISSN 0022-3166.

Buchner DM \& Larson EB. (1987). Falls and fractures in patients with Alzheimer-type dementia. JAMA, Vol.257, No.11, (March 1987), pp. 1492-5, ISSN 0098-7484.

Buell JS \& Dawson-Hughes B. (2008). Vitamin D and neurocognitive dysfunction: Preventing Decline? Molecular Aspects of Medicine, Vol.29, No.6, (December 2008), pp. 415-22, ISSN 0098-2997.

Buell JS, Dawson-Hughes B, ScottTM, Weiner DE, Dallal GE, Qui WQ, Bergethon P, Rosenberg IH, Folstein MF, Patz S, Bhadelia RA \& Tucker KL. (2010). 25Hydroxyvitamin D, dementia, and cerebrovascular pathology in elders receiving home services. Neurology, Vol.74, No.1, (January 2010), pp. 18-26, ISSN 0028-3878.

Chen TF, Huang RF, Lin SE, Lu JF, Tang MC \& Chiu MJ. (2010). Folic acid potentiates the effect of memantine on spatial learning and neuronal protection in an Alzheimer's disease transgenic model. J Alzheimers Dis, Vol.20, No.2, pp.607-15, ISSN 1387-2877.

Christen Y. (2000). Oxidative stress and Alzheimer disease. Am J Clin Nutr, Vol.71, No.2, (February 2000), pp.S621-9, ISSN 0002-9165.

Clarke R, Birks J, Nexo E, Ueland PM, Schneede J, Scott J, Molloy A \& Evans JG. (2007). Low vitamin B-12 status and risk of cognitive decline in older adults. Am J Clin Nutr, Vol.86, No.5, (November 2007),pp. 1384-91, ISSN 0002-9165.

Cutler RG, Kelly J, Storie K, Pedersen WA, Tammara A, Hatanpaa K, Troncoso JC, Mattson MP. (2004). Involvement of oxidative stres-induced abnormalities in ceramide and cholesterol metabolism in brain aging and Alzheimer's disease. Proc Natl Acad Sci USA, Vol.101, No.9, (February 2009), pp. 2070-5, ISSN 0027-8424.

Dai Q, Borenstein AR, Wu Y, Jackson JC \& Larson EB. (2006). Fruit and vegetable juices and Alzheimer's disease: the Kame Project. Am J Med, Vol.119, No.9, (September 2006), pp. 751-9, ISSN 0002-9343.

Das UN. (2008). Folic acid and polyunsaturated fatty acids improve cognitive function and prevent depression, dementia, and Alzheimer's disease-but how and why? Prostaglandins Leukot Essent Fatty Acids, Vol.78, No.1, (January 2008), pp. 11-9, ISSN 0952-3278.

de Lau LM, Refsum H, Smith AD, Johnston C \& Breteler MM. (2007). Plasma folate concentration and cognitive performance: Rotterdam Scan Study. Am J Clin Nutr, Vol.86, No.3, (September 2007), pp. 728-34, ISSN 0002-9165.

Denisova NA, Booth SL. (2005). Vitamin K and sphingolipid metabolism: Evidence to date. Nutr Rev, Vol.63, No.4, (July 2010), pp. 111-21, ISSN 0029-6643.

Devore EE, Grodstein F, van Rooij FJA \& Hofman A. (2010). Dietary antioxidants and long term risk of dementia. Arch Neurol, Vol.67, No.7, (July 2010), pp. 819-25, ISSN 00029262.

Dufouil C, Alperovitch A, Ducros V \& Tzourio C. (2003). Homocysteine, white matter hyperintensities, and cognition in healthy elderly people. Ann Neurol, Vol.53, No.2, (February 2003), pp. 214-21, ISSN 0364-5134.

Durga J, van Boxtel MP, Schouten EG, Kok FJ, Jolles J, Katan MB \& Verhoef P. (2007). Effect of 3-year folic acid supplementation on cognitive function in older adults in the FACIT trial: a randomised, double blind, controlled trial. Lancet, Vol.369, No.9557, (January 2007), pp. 208-16, ISSN 0140-6736. 
Engelhart MJ, Geerlings MI, Ruitenberg A, van Switen JC, Hofman A, Witteman JC \& Breteler MM. (2002). Dietary intake of antioxidants and risk of Alzheimer disease. JAMA, Vol.287, No.24, (June 2002), pp. 3223-9, ISSN 0098-7484.

Eussen SJ, de Groot LC, Joosted LW, Bloo RJ, Clarke R, Ueland PM, Schneede J, Blom HJ, Hoefnagels WH \& van Staveren WA. (2006). Effect of oral vitamin B-12 with or without folic acid on cognitive function in older people with mild vitamin B-12 deficiency: a randomised, placebo controlled trial. Am J Clin Nutr, Vol.84, No.2, (August 2006), pp. 361-70, ISSN 0002-9165.

Fekkes D, van der Cammen TJ, Van Loon CP, Verschoor C, van Harskamp F, de KI, Schudel WJ \& Pepplinkhuizen L. (1998). Abnormal amino acid metabolism in patients with early stage Alzheimer dementia. J Neural Transm, Vol.105, No.2-3, pp. 287-94, ISSN 0300-9564.

Fioravanti M, Ferrario E, Massaia M, Cappa G, Rivolta G, Grossi E \& Buckley AE. (1998). Low folate levels in the cognitive decline of elderly patients and the efficacy of folate as a treatment for imprpving memory deficits. Arch Gerontol Geriatr, Vol.26, No.1, (January-February 1998), pp. 1-13, ISSN 0167-4943.

Foy CJ, Passmore AP, Vahidassr MD, Young IS \& Lawson JT. (1999). Plasma chain-breaking antioxidants in Alzheimer's disease, vascular dementia and Parkinson's disease. Q J Med, Vol.92, No.1, (January 1999), pp. 39-45, ISSN 0033-5622.

Gezen-Ak D, Dursun E, Ertan T, Hanagasi H, Gürvit H, Emre M, Eker E, Ozturk M, Engin F \& Yilmazer S. (2007). Association between vitamin D receptor gene polymorphism and Alzheimer's disease. Tohoku J Exp Med, Vol.212, No.3, (July 2007), pp. 275-82, ISSN 0040-8727.

Goodman AB. (2006). Retinoid receptors, transporters, and metabolizers as therapeutic targets in late onset Alzheimer disease. J Cell Physiol, Vol.209, No.3, (December 2006), pp. 598-603, ISSN 0021-9541.

Grant WB. (2009). Does vitamin D reduce the risk of dementia? J Alzheimers Dis, Vol.17, No.1, pp. 151-9, ISSN 1387-2877.

Gray SL, Anderson ML, Crane PK, Breitner JC, McCormick W, Bowen JD, Teri L \& Larson E. (2008). Antioxidant vitamin supplement use and risk of dementia or Alzheimer's disease in older adults. J Am Geriatr Soc, Vol.56, No.2, (February 2008), pp. 291-5, ISSN 0002-8614.

Haan MN, Miller JW, Aiello AE, Whitmer RA, Jagust WJ, Mungas DM, Allen LH \& Green R. (2007). Homocysteine, B vitamins, and the incidence of dementia and cognitive impairment: results from the Sacramento Area Latino Study on Aging. Am J Clin Nutr, Vol.85, No.2, (February 2007), pp. 511-7, ISSN 0002-9165.

Haller J, Weggemans RM, Lammi-Keefe CJ \& Ferry M. (1996). Changes in the vitamin status of elderly Europeans: plasma vitamins A, E, B-6, B-12, folic acid and carotenoids. Eur J Clin Nutr, Vol.50, No. Suppl 2, (July 1996), pp. S32-36, ISSN 0954-3007.

Hassan A, Hunt BJ, O'Sullivan M, Bell R, D'Souza R, Jeffery S, Bamford JM, Markus HS. (2004). Homocysteine is a risk factor for cerebral small vessel disease acting via endothelial function. Brain, Vol.127, No.1, (January 2004), pp. 212-9, ISSN 00068950.

Head E, Nukala VN, Fenoglio KA, Muggenburg BA, Cotman CW \& Sullivan PG. (2009). Effects of age, dietary, and behavioral enrichment on brain mitochondria in a 
canine model of human aging. Exp Neurol, Vol.220, No.1, (November 2009), pp. 1716, ISSN 0014-4886.

Herrmann W, Obeid R. (2007). Biomarkers of folate and vitamin B(12) status in cerebrospinal fluid. Clin Chem Lab Med, Vol.45, No.12, pp. 1614-20, ISSN 1434-6621.

Hu P, Bretsky P, Crimmins EM, Guralnik JM, Reuben DM \& Seeman TE. (2006). Association between serum beta-carotene levels and decline of cognitive function in highfunctioning older persons with or without apolipoprotein E4 alleles: MacArthur studies of successful aging. J Gerontol A Biol Sci Med Sci, Vol.61, No.6, (June 2006), pp. 616-20, ISSN 1079-5006.

Hvas AM, Juul S, Lauritzen L, Nexo E \& Ellegaard J. (2004). No effect of vitamin B-12 treatment on cognitive function and depression: a randomized placebo controlled study. J Affect Disord, Vol.81, No.3, (September 2004), pp. 269-73, ISSN 0165-0327.

Hyun DH, Mughal MR, Yang H, Lee JH, Ko EJ, Hunt ND, de Cabo R, Mattson MP. (2010). The plasma membrane redox system is impaired by amyloid $\beta$-peptide in the hippocampus and cerebral cortex of 3xTgAD mice. Exp Neurol, Vol.225, No.2, (October 2010), pp. 423-9, ISSN 0014-4886.

Jacques PF, Selhub J, Bostom AG, Wilson PW \& Rosenberg IH. (1999). The effect of folic acid fortification on plasma folate and total homocysteine concentrations. $N$ Eng J Med, Vol.340, No.19, (May 1999), pp. 1449-54, ISSN 0028-4793.

Joosten E, van den BA, Riezler R, Naurath HJ, Lindenbaum J, Stabler SP \& Allen RH. (1993). Metabolic evidence that deficiencies of vitamin B-12 (cobalamin), folate, and vitamin B-\& occur commonly in elderly people. Am J Clin Nutr, Vol.58, No.4, (October 1993), pp. 468-76, ISSN 0002-9165.

Joseph JA, Shukitt-Hale B, Denisova NA, Prior RL, Cao G, Martin A, Taglialatela G \& Bickford PC. (1998). Long- term dietary strawberry, spinach, or vitamin E supplementation retards the onset of age- related neuronal signal transduction and cognitive behavioral deficits. J Neurosci, Vol.18, No.19, (October 1998), pp. 8047-55, ISSN 0270-6474.

Joseph JA, Shukitt-Hale B, Denisova NA, Bielinski D, Martin A, McEwen JJ \& Bickford PC. (1999). Reversals of age-related declines in neuronal signal transduction, cognitive, and motor behavioral deficits with blueberry, spinach, or strawberry dietary supplementation. J Neurosci, Vol.19, No.18, (September 1999), pp. 8114-21, ISSN 0270-6474.

Kalmijn S, Launer LJ, Lindemans J, Bots ML, Hofman A \& Breteler MM. (1999). Total homocysteine and cognitive decline in a community-based sample of elderly subjects: the Rotterdam study. Am J Epidemiol, Vol.150, No.3, (August 1999), pp. 283-9, ISSN 0002-9262.

Kang JH, Cook N, Manson J, Buring JE \& Grodstein F. (2006). A randomized trial of vitamin E supplementation and cognitive function in women. Arch Intern Med, Vol.166, No.22, (December 2006), pp. 2462-8, ISSN 0003-9926.

Kipen E, Helme RD, Wark JD \& Flicker L. (1995). Bone density, vitamin D nutrition, and parathyroid hormone levels in women with dementia. J Am Geriatr Soc, Vol.43, No.10, (October 1995), pp. 1088-91, ISSN 0002-8614.

Kivipelto M, Annerbo S, Hultdin J, Backman L, Viitanen M, Fratiglioni L \& Lokk J. (2009). Homocysteine and holo-transcobalamin and the risk of dementia and Alzheimers 
disease: a prospective study. Eur J Neurol, Vol.16, No.7, (July 2009), pp. 808-13, ISSN 1351-5101.

Knopman DS. (1998). Current pharmacotherapies for Alzheimer's disease. Geriatrics, Vol.53, No. Suppl.1, (September 1998), pp. S31-4, ISSN 0016-867X.

Kohlmeier M, Solomon A, Saupe J \& Shearer MJ. (1996). Transport of vitamin K to bones in humans. J Nutr,Vol. 126, No.4 Suppl1, (April 1996), pp. S1192-6, ISSN 0022-3166.

Kronenberg G, Colla M \& Endres M. (2009). Folic acid, neurodegenerative and neuropsychiatric disease. Curr Mol Med, Vol.9, No.3, (April 2009), pp. 315-23, ISSN 1566-5240.

Kruman II, Culmsee C, Chan SL, Kruman Y, Guo Z, Penix L \& Mattson MP. (2000). Homocysteine elicits a DNA damage response in neurons that promotes apoptosis and hypersensitivity to excitotoxicity. J Neurosci, Vol.20, No.18, (September 2000), pp. 6920-6, ISSN 0270-6474.

Kuipers EJ, Uyterlinde AM, Pena AS, Hazenberg HJ, Bloemena E, Lindeman J, KlinkenbergKnol EC \& Meuwissen SG. (1995). Increase of Helicobacter pylori-associated corpus gastritis during acid suppressive therapy: implications for long term safety. Am J Gastroenterol, Vol.90, No.9, (September 1995), pp. 1401-6, ISSN 0002-9270.

Kuipers EJ, Lundell L, Klinkenberg-Knol EC, Havu N, Festen HP, Liedman B, Lamers CB, Jansen JB, Dalenback J, Snel P, Nelis GF \&Meuwissen SG. (1996). Atrophic gastritis and Helicobacter pylori infection in patients with reflux esophagitis treated with omeprazol or fundoplication. N Engl J Med, Vol.334, No.16, (April 1996), pp. 101822, ISSN 0028-4793.

Landfield PW \& Cadwallader-Neal L. (1998). Long term treatment with calcitriol $(1,25$ $(\mathrm{OH}) 2$ vit D3) retardsa biomarker of hippocampal aging in rats. Neurobiol Aging, Vol.19, No.5, (September-October 1998), pp. 469-77, ISSN 0197-4580.

Lewerin C, Matousek M, Steen G, Johansson B, Steen B \& Nilsson-Ehle H. (2005). Significant correlations of plasma homocysteine and serum methylmalonic acid with movement and cognitive performance in elderly subjects but no improvement from short-term vitamin therapy: a placebo-controlled randomized study. Am J Clin Nutr, Vol.81, No.5, (May 2005), pp. 1155-62, ISSN 0002-9165.

Lindahl B, Eriksson L, Spillmann D, Caterson B \& Lindahl U. (1996). Selective loss of cerebral keratan sulfate in Azheimer's disease. J Biol Chem, Vol.271, No.29, (July 1996), pp. 16991-4, ISSN 0021-9258.

Lokk J. (2003). News and views on folate and elderly persons. J Gerontol A Biol Sci Med Sci, Vol.58, No.4, (April 2003), pp. 354-61, ISSN 1079-5006.

Luchsinger JA, Tang MX, Shea S, Miller J, Green R \& Mayeux R. (2004). Plasma homocysteine levels and risk of Alzheimer disease. Neurology, Vol.62, No.11, (June 2004), pp. 1972-6, ISSN 0028-3878.

Lundell L, Havu N, Miettinen P, Myrvold HE, Wallin L, Julkunen R, Levander K, Hatlebakk JG,

Liedmann B, Lamm M, Malm A \& Walan A: Nordic Gerd Study Group. (2006). Changes of gastric mucosal architecture during long-term omeprazole therapy: results of a randomized clinical trial. Aliment Pharmacol Ther, Vol.23, No.5, (March 2006), pp. 639-47, ISSN 0269-2813.

Martin A, Foxall T, Blumberg JB \& Meydani M. (1997). Vitamin E inhibits low-density lipoprotein-induced adhesion of monocytes to human aortic endothelial cells in 
vitro. Arterioscler Thromb Vasc Biol, Vol.17, No.3, (March 1997), pp. 429-36, ISSN 1079-5642.

Mattson MP. (2004). Pathways towards and away from Alzheimer's disease. Nature, Vol.430, No.7000, (August 2004), pp. 631-9, ISSN 0028-0836.

Maxwell CJ, Hicks MS, Hogan DB, Basran J \& Ebly EM. (2005). Supplemental use of antioxidant vitamins and subsequent risk of cognitive decline and dementia. Dement Geriatr Cogn Disord, Vol.20, No.1, pp. 45-51, ISSN 1420-8008.

McCaddon A, Davies G, Hudson P, Tandy S \& Cattell H. (1998). Total serum homocysteine in senile dementia of Alzheimer type. Int J Geriatr Psychiatry, Vol.13, No.4, (April 1998), pp. 235-9, ISSN : 0885-6230.

McCaddon A, Hudson P, Davies G, Hughes A, Williams JH \& Wilkinson C. (2001). Homocysteine and cognitive decline in healthy elderly. Dement Geriatr Cogn Disord, Vol.12, No.5, (September-October 2001), pp. 309-13, ISSN 1420-8008.

McCaddon A, Regland B, Hudson P \& Davies G. (2002). Functional vitamin B (12) deficiency and Alzheimer disease. Neurology, Vol.58, No.9, (May 2002), pp. 1395-9, ISSN 00283878

McMahon JA, Green TJ, Skeaff CM, Knight RG, Mann JI \& Williams SM. (2006). A controlled trial of homocysteine lowering and cognitive performance. N Eng J Med, Vol.354, No.26, (June 2006), pp. 2764-72, ISSN 0028-4793.

McNeill G, Avenell A, Campbell MK, Cook JA, Hannaford PC, Kilonzo MM, Mile AC, Ramsay CR, Seymour DG, Stephen AI \& Vale LD. (2007). Effect of multivitamin and multimineral supplementation on cognitive function in men and women aged 65 years and over: a randomised controlled trial. Nutr J, Vol.2, No.1, (May 2007), pp. 6-10, ISSN 1475-2891.

Meydani SN, Meydani M, Blumberg JB, Leka LS, Siber G, Loszewski R, Thompson C, Pedrosa MC, Diamond RD \& Stollar BD. (1997). Vitamin E supplementation and in vivo immune response in healthy elderly subjects. A randomised controlled trial. $J$ Am Med Assoc, Vol.277, No.17, (May 1997), pp. 1380-6, ISSN 0002-9955.

Micheau J, Durkin TP, Destrade C, Rolland Y \& Jaffard R. (1985). Chronic administration of sulbutiamine improves long term memory formation in mice: possible cholinergic mediation. Pharmacol Biochem Behav, Vol.23, No.2, (August 1985), pp. 195-8, ISSN 0091-3057.

Miller ER 3rd, Pastor-Barriuso R, Dala D, Riemersma RA, Appel LJ \& Guallar E. (2005). Meta-analysis: high- dosage vitamin E supplementation may increase all-cause mortality. Ann Intern Med, Vol.142, No.1, (January 2005), pp. 37-46, ISSN 0003-4819.

Miller LJ \& Chacko R. (2004). The role of cholesterol and statins in Alzheimer's disease. Ann Pharmacother, Vol.38, No.1, (January 2004), pp. 91-8, ISSN 1060-0280.

Mooijaart SP, Gussekloo J, Frölich M, Jolles J, Stott DJ, Westendorp RG \& de Craen AJ. (2005). Homocysteine, vitamin B-12, and folic acid and the risk of cognitive decline in old age: the Leiden 85-Plus study. Am J Clin Nutr, Vol.82, No.4, (October 2005), pp. 627-35, ISSN 0002-9165.

Morris MS, Jacques PF, Rosenberg IH \& Selhub J. (2001). Hyperhomocysteinemia associated with poor recall in the third National Health and Nutrition Examination Survey. Am J Clin Nutr, Vol.73, No.5, (May 2001), pp. 927-33, ISSN 0002-9165. 
Morris MC, Evans DA, Bienias JL, Tangney CC \& Wilson RS. (2002). Vitamin E and cognitive decline in older persons. Arch Neurol, Vol.59, No.7, (July 2007), pp. 112532, ISSN 0003-9942.

Morris MC, Evans DA, Tangney CC, Bienias JL, Wilson RS, Aggarwal NT \& Scherr PA. (2005a ). Relation of tocopherol forms to incident Alzheimer disease and to cognitive change. Am J Clin Nutr, Vol.81, No.2, (February 2005), pp. 508-14, ISSN 0002-9165.

Morris MC, Evans DA, Bienias JL, Tangney CC, Hebert LE, Scherr PA \& Schneider JA. $(2005 b)$. Dietary folate and vitamin B12 intake and cognitive decline among community-dwelling older persons. Arch Neurol, Vol.62, No.4, (April 2005), pp. 6415, ISSN 0003-9942.

Morris MC, Evans DA, Schneider JA, Tangney CC, Bienias JL \& Aggarwal NT. (2006a ). Dietary folate and vitamins B-12 and B-6 not associated with incident Alzheimer's disease. J Alzheimers Dis, Vol.9, No.4, (August 2006), pp. 435-43, ISSN 1387-2877.

Morris MC, Evans DA, Tangney CC, Bienias JL \& Wilson RS. (2006b ). Associations of vegetable and fruit consumption with age-related cognitive change. Neurology, Vol.67, No.8, (October 2006), pp. 1370-6, ISSN 0028-3878.

Nilsson K, Gustafson L, Faldt R, Andersson A, Brattstrom L, Lindgren A, Israelson B \& Hultberg B. (1996). Hyperhomocysteinaemia- a common finding in psychogeriatric population. Eur J Clin Invest, Vol.26, No.10, (October 1996), pp. 8534-9, ISSN 00142972.

Nilsson K, Gustafson L \& Hultberg B. (1999). Plasma homocysteine is a sensitive marker for tissue deficiency of both cobalamines and folates in a psychogeriatric population. Dement Geriatr Cogn Disord, Vol.10, No.6, (November-December 1999), pp. 476-82, ISSN 1420-8008.

Obeid R, McCaddon A \& Herrman W. (2007). The role of hyperhomocysteinemia and Bvitamin deficieny in neurological and psychiatric diseases. Clin Chem Lab Med, Vol.45, No.12, pp. 1590-606, ISSN 1434-6621.

Ortega RM, Requejo AM, Lopez-Sobaler AM, Andres P, Navia B, Perea JM \& Robles F. (2002). Cognitive function in elderly people is influenced by Vitamin E status. $J$ Nutr, Vol.132, No.7, (July 2002), pp. 2065-8, ISSN 0022-3166.

Paleologos M, Cumming RG \& Lazarus R. (1998). Cohort study of Vitamin C intake and cognitive impairment. Am J Epidemiol, Vol.148, No.1, (July 1998), pp. 45-50, ISSN 0002-9262.

Parnetti L, Bottiglieri T \& Lowenthal D. (1997). Role of homocysteine in age related vascular and non-vascular disease. Aging (Milano), Vol.9, No.4, (August 1997), pp. 241-57, ISSN 0011-3662.

Pauli RM \& Haun JM. (1979). Warfarin embryopathy. Lancet, Vol.2, No.8134, (July 1999), pp. 144, ISSN 0140-6736.

Perkins AJ, Hendrie HC, Callahan CM, Gao S, Unverzagt FW, Xu Y, Hall KS \& Hui SL. (1999). Association of antioxidants with memory in a multiethnic elderly sample using the Third National Health and Nutrition Examination Survey. Am J Epidemiol, Vol.150, No.1, (July 1999), pp. 37-44, ISSN 0002-9262.

Perrig WJ, Perrig P \& Stahelin HB. (1997). The relation between antioxidants and memory performence in the old and very old. J Am Geriatr Soc, Vol.45, No.6, (June 1997), pp. 718-24, ISSN 0002-8614. 
Petersen RC, Thomas RG, Grundman M, Bennett D, Doody R, Ferris S, Galasko D, Jin S, Kaye J, Levey A, Pfeiffer E, Sano M, van Dyck CH \& Thal LJ. (2005). Vitamin E and donepezil for the treatment of mild cognitive impairment. N Eng J Med, Vol.352, No.23, (June 2005), pp. 2379-88, ISSN 0028-4793.

Pietrzik K \& Bronstrup A. (1997). Causes and consequences of hyperhomocyst(e)inemia. Int J Vitam Nutr Res, Vol.67, No.5, pp. 389-95, ISSN 0300-9831.

Pitchumoni SS \& Doraisway PM. (1998). Current status of antioxidant therapy for Alzheimer's Disease. J Am Geriatr Soc, Vol.46, No.12, (December 1998), pp. 1566-72, ISSN 0002-8614.

Pratico D \& Delanty N. (2000). Oxidative injury in diseases of the central nervous system: focus on Alzheimer's disease. Am J Med, Vol.109, No.7, (November 2000), pp. 57785, ISSN 0002-9343.

Presse N, Shatenstein B, Kergoat MJ \& Ferland G. (2008). Low vitamin K intakes in community-dwelling elders at an early stage of Alzheimer's disease. J Am Diet Assoc, Vol.108, No.12, (December 2008), pp.2095-9, ISSN 0002-8223.

Prieto AL, Weber JL, Tracy S, Heeb MJ \& Lai C. (1999). Gas 6, a ligand for the receptor tyrosine kinase tyro 3, is widely expressed in the central nervous system. Brain Res, Vol.816, No.2, (January 1999), pp. 646-61, ISSN 0006-8993.

Prins ND, Den Heijer T, Hofman A, Koudstaal PJ, Jolles J, Clarke R \& Breteler MM. (2002). Homocysteine and cognitive function in the elderly: Rotterdam Scan Study. Neurology, Vol.59, No.9, (November 2002), pp. 1375-80, ISSN 028-3878.

Rabaneda LG, Carrasco M, Lopez-Toledano MA, Murillo-Carretero M, Ruiz FA, Estrada C \& Castro C. (2008). Homocysteine inhibits proliferation of neuronal precursors in the mouse adult brain by impairing the basic fibroblast growth factor signaling cascade and reducing extracellular regulated kinase-dependent cyclin E expression. FASEB J, Vol.22, No.11, (November 2008), pp. 3823-35, ISSN 0892-6638.

Rampersaud GC, Kauwell GP \& Bailey LB. (2003). Folate: a key to optimizing health and reducing disease risk in the elderly. J Am Coll Nutr, Vol.22, No.1, (February 2003), pp. 1-8, ISSN 0731-5724.

Ravaglia G, Forti P, Maioli F, Martelli M, Servadei L, Brunatti N, Porcellini E \& Licastro F. (2005). Homocysteine and folate as risk factors for dementia and Alzheimer disease. Am J Clin Nutr, Vol.82, No.3, (September 2005), pp. 636-43, ISSN 0002-9165.

Refsum H, Ueland PM, Nygard O \& Vollset SE. (1998). Homocysteine and cardiovascular disease. Annu Rev Med, Vol.49, No.1, pp. 31-62, ISSN 0066-4219.

Reiter R.J. (1995). Oxidative processes and antioxidative defence mechanisms in the aging brain. FASEB J, Vol.9, No.7, (April 1995), pp. 526-33, ISSN 0892-6638.

Remington R, Chan A, Paskavitz J \& Shea TB. (2009). Efficacy of a vitamin/nutriceutical formulation for moderate-stage to later stage Alzheimer's disease: a placebocontrolled pilot study. Am J Alzheimers Dis Other Demen, Vol.24, No.1, (FebruaryMarch 2009), pp. 27-33, ISSN 1533-3175.

Riedel WJ, Jorissen B \& Nutrients L. (1998). Age and cognitive function. Curr Opin Clin Nutr Metab Care, Vol.1, No.6, (November 1998), pp. 579-85, ISSN 163-1950.

Sahin M, Karauzum SB, Perry G, Smith MA \& Aliciguzel Y. (2005). Retinoic acid isomers protect hippocampal neurons from amyloid-beta induced neurodegeneration. Neurotox Res, Vol.7, No.3, pp. 243-50, ISSN 1029-8428. 
Sano M, Ernesto C, Thomas RG, Klauber MR, Schafer K, Grundman M, Woodbury P, Growdon J, Cotman CW, Pfeiffer E, Schneider LS \& Thal LJ. (1997). A controlled trial of selegiline, alpha-tocopherol, or both as treatment for Alzheimer's disease. The Alzheimer's Disease Cooperative Study. N Eng J Med, Vol.336, No.17, (April 1997), pp. 1216-22, ISSN 0028-4793.

Sato Y, Iwamoto J, Kanoko T \& Satoh K. (2005). Amelioration of osteoporosis and hypovitaminosis D by sunlight exposure in hospitalized, elderly women with Alzheimer's disease: a randomized controlled trial. Journal of BoneEMineral Research, Vol.20, No.8, (August 2005), pp. 1327-33, ISSN 0884-0431.

Saupe J, Shearer MJ \& Kohlmeier M. (1993). Phylloquinone transport and its influence on ycarboxyglutamate residues of osteocalcin in patients on hemodialysis. Am J Clin Nutr, Vol.58, No.2, (August 1993), pp. 204-8, ISSN 0002-9165.

Saxena SP, Fan T, Li M, Israels ED \& Israels LG. (1997). A novel role for vitamin K, in a tyrosine phosphorylation cascade during chick embryogenesis. J Clin Invest, Vol.99, No.4, (February 1997), pp. 602-7, ISSN 0021-9738.

Scarmeas N, Stern Y, Tang MX, Mayeux R \& Luchsinger JA. (2006). Mediterranean diet and risk for Alzheimer's disease. Ann Neurol, Vol.59, No.6, (June 2006), pp. 912-21, ISSN 0364-5134.

Scarmeas N, Stern Y, Mayeux R, Manly JJ, Schupf N \& Luchsinger JA. (2009). Mediterranean diet and mild cognitive impairment. Arch Neurol, Vol.66, No.2, (February 2009), pp. 216-25, ISSN 0003-9942.

Scott TM, Peter I, Tucker KL, Arsenault L, Bergethon P, Bhadelia R, Buell J, Collins L, Dashe JF, Griffith J, Hibberd P, Leins D, Liu T, Ordovas JM, Patz S, Price LL, Qiu WQ, Sarnak M, Selhub J, Smaldone L, Wagner C, Wang L, Weiner D, Yee J, Rosenberg I \& Folstein M. (2006). The Nutrition, Aging, and Memory in Elders (NAME) study: design and methods for a study of micronutrients and cognitive function in a homebound elderly population. Int J Geriatr Psychiatr, Vol.21, No.6, (June 2006), pp. 519-28, ISSN 0885-6230.

Scranton TW, Iwata M \& Carlson SS. (1993). The SV-2 protein of synaptic vesicles is a keratan sulfate proteoglycan. J Neurochem, Vol.61, No.1, (July 1993), pp. 29-44, ISSN 0022-3042.

Selhub J, Jacques PF, Wilson PW, Rush D \& Rosenberg IH. (1993). Vitamin status and intake as primary determinants of homocysteinemia in an elderly population. J Am Med Assoc, Vol.270, No.22, (December 1993), pp. 2693-8, ISSN 0002-9955.

Selhub J, Bagley LC, Miller J \& Rosenberg IH. (2000). B vitamins, homocysteine, and neurocognitive function in the elderly. Am J Clin Nutr, Vol.71, No.2, (February 2000), S614-20, ISSN 0002-9165.

Selhub J. (2008). Public health significance of elevated homocysteine. Food Nutr Bull, Vol.29, No.2 Suppl), pp. S116-25, ISSN 0379-6721.

Seshadri S, Beiser A, Selhub J, Jacques PF, Rosenberg IH, D'Agostino RB, Wilson PW \& Wolf PA. (2002). Plasma homocysteine as a risk factor for dementia and Alzheimer's disease. N Eng J Med, Vol.346, No.7, (February 2002), pp. 476-83, ISSN 0028-4793.

Shahidi S, Komaki A, Mahmoodi M, Atrvash H \& Ghodrati M. (2008). Ascorbic acid supplementation could affect passive avoidance learning and memory in rats. Brain Res Bull, Vol.76, No.1-2, (May 2008), pp.109-13, ISSN 0361-9230. 
Sinclair AJ, Bayer AJ, Johnston J, Warner C \& Maxwell SR. (1998). Altered plasma antioxidant status in subjects with Alzheimer's disease and vascular dementia. Int $J$ Geriatr Psychiatry, Vol.13, No.12, (December 1998), pp. 840-5, ISSN 0885-6230.

Smith AD, Stephen MS, de Jager CA, Whitbread P, Johnston C, Agacinski G, Oulhaj A, Bradley KM, Jacoby R \& Refsum H. (2010). Homocysteine-lowering by B vitamins slows the rate of accelerated brain atrophy in mild cognitive impairment: a randomized controlled trial. In: PLoS ONE, 5(9), 17.05.2011, Available from e12244. doi:10.1371/journal.pone.0012244.

Sommer BR, Hoff AL \& Costa M. (2003). Folic acid supplementation in dementia: a preliminary report. J Geriatr Psychiatry Neurol, Vol.16, No.3, (September 2003), pp. 156-9, ISSN 0891-9887.

Stott DJ, MacIntosh G, Lowe GD, Rumley A, McMahon AD, Langhorne P, Tait RC, O’Reilly DS, Spilg EG, MacDonald JB, MacFarlane PW, Westendorp RG. (2005). Randomized controlled trial of homocysteine-lowering vitamin treatment in elderly patients with vascular disease. Am J Clin Nutr, Vol.82, No.6, (December 2006), pp. 1320-6, ISSN 0002-9165.

Sutherland MK, Somerville MJ, Yoong LK, Bengeron C, Haussler MR \& McLachlan DR. (1992). Reduction of vitamin D hormone receptor mRNA levels in Alzheimer as compared to Huntington hippocampus: correlation with calbindin -28k mRNA levels. Brain Res Mol Brain Res, Vol.13, No.3, (April 1992), pp. 239-50, ISSN 0169$328 X$.

Teunissen CE, Blom AH, Van Boxtel MP, Bosma H, de Bruijn C, Jolles J, Wauters BA, Steinbusch HW \& de Vente J. (2003). Homocysteine: a marker for cognitive performance? A longitudinal follow-up study. J Nutr Health Aging, Vol.7, No.3, pp. 153-9, ISSN 1279-7707.

Troen AM, Shea-Budgell M, Shukitt-Hale B, Smith DE, Selhub J \& Rosenberg IH. (2008). Bvitamin deficiency causes hyperhomocysteinemia and vascular cognitive impairment in mice. Proc Natl Acad Sci USA, Vol.105, No.34, (August 2008), pp. 12474-9, ISSN 0027-8424.

Tucker KL, Qiao N, Scott T, Rosenberg I \& Spiro A 3rd. (2005). High homocysteine and low $B$ vitamins predict cognitive decline in aging men: the Veterans Affairs Normative Aging Study. Am J Clin Nutr, Vol.82, No.3, (November 2005), pp. 627-35, ISSN 00029165.

Ueland PM \& Refsum H. (1989). Plasma homocysteine, a risk factor for vascular disease: plasma levels in health, disease, and drug therapy. J Lab Clin Med, Vol.114, No.5, (November 1989), pp. 473-501, ISSN 0022-2143.

van Oort FV, Melse-Boonstra A, Brouwer IA, Clarke R, West CE, Katan MB \& Verhoef P. (2003). Folic acid and reduction of plasma homocysteine concentrations in older adults: a dose-response study. Am J Clin Nutr, Vol.77, No.5, (May 2003), pp. 131823, ISSN 0002-9165.

van Uffelen JG, Chin A, Paw MJ, Hopman-Rock M \& van Mechelen W. (2007). The effect of walking and vitamin B supplementation on quality of life in community-dwelling adults with mild cognitive impairment: a randomized, controlled trial. Qual Life Res, Vol.16, No.7, (September 2007), pp. 1137-46, ISSN 0962-9343. 
Varadarajan S, Yatin S, Aksenova M \& Butterfield DA. (2000). Review: Alzheimer's amyloid beta-peptide-associated free radical oxidative stress and neurotoxicity. J Struct Biol, Vol.130, No.2-3, (June 2000), pp. 184-208, ISSN 1047-8477.

Vivekananthan DP, Penn MS, Sapp SK, Hsu A \& Topol EJ. (2003). Use of antioxidant vitamins for the prevention of cardiovascular disease: meta-analysis of randomised trials. Lancet, Vol.361, No.9374), pp. 2017-23, ISSN 0140-6736.

Wahlin A, Hill RD, Winblad B \& Backman L. (1996). Effects of serum vitamin B12 and folate status on episodic memory performance in very old age: a population- based study. Psychol Aging, Vol.11, No.3, (September 1996), pp. 487-96, ISSN 0882-7974.

Wald DS, Bishop L, Wald NJ, Law M, Hennessy E, Weir D, McPartlin J \& Scott J. (2001). Randomized trial of folic acid supplementation and serum homocysteine levels. Arch Intern Med, Vol.161, No.5, (March 2001), pp. 695-700, ISSN 0003-9926.

Wang HX, Wahlin A, Basun H, Fastbom J, Winblad B \& Fratiglioni L. (2001). Vitamin B(12) and folate in relation to the development of Alzheimer's disease. Neurology, Vol.56, No.9, (May 2001), pp. 1188-94, ISSN 0028-3878.

Wolters M, Strohle A \& Hahn A. (2004). Age-associated changes in the metabolism of vitamin B (12) and folic acid: prevalance, aetiopathogenesis and pathophysiological consequences. Z Gerontol Geriatr, Vol.37, No.2, (April 2004), pp. 109-35, ISSN 09486704 .

Wolters M, Hickstein M, Flintermann A, Tewes U \& Hahn A. (2005). Cognitive performance in relation to vitamin status in healthy elderly German women-the effect of 6month multivitamin supplementation. Prev Med, Vol.41, No.1, (July 2005), pp. 2539, ISSN 0091-7435.

Yagami T, Ueda K, Asakura K, Sakaeda T, Nakazato H, Huroda T, Hata S, Sakaguchi G, Itoh N, Nakano T, Kambayashi Y \& Tsuzuki H. (2002). Gas6 rescues cortical neurons from amyloid $\beta$ protein-induced apoptosis. Neuropharmacology, Vol.43, No.8, (December 2002), pp. 1289-96, ISSN 0028-3908.

Zandi PP, Anthony JC, Khachaturian AS, Stone SV, Gustafson D, Tschanz JT, Norton MC, Weish-Bohmer KA, Breitner JC. (2004). Reduced risk of Alzheimer disease in users of antioxidant vitamin supplements. Arch Neurol, Vol.61, No.1, (January 2004), pp. 82-8, ISSN 0003-9942. 


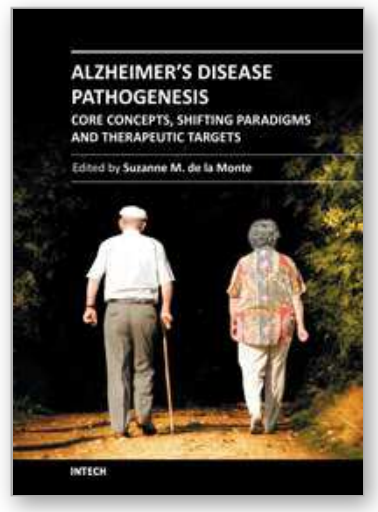

\author{
Alzheimer's Disease Pathogenesis-Core Concepts, Shifting \\ Paradigms and Therapeutic Targets \\ Edited by Dr. Suzanne De La Monte
}

ISBN 978-953-307-690-4

Hard cover, 686 pages

Publisher InTech

Published online 12, September, 2011

Published in print edition September, 2011

Alzheimer's Disease Pathogenesis: Core Concepts, Shifting Paradigms, and Therapeutic Targets, delivers the concepts embodied within its title. This exciting book presents the full array of theories about the causes of Alzheimer's, including fresh concepts that have gained ground among both professionals and the lay public. Acknowledged experts provide highly informative yet critical reviews of the factors that most likely contribute to Alzheimer's, including genetics, metabolic deficiencies, oxidative stress, and possibly environmental exposures. Evidence that Alzheimer's resembles a brain form of diabetes is discussed from different perspectives, ranging from disease mechanisms to therapeutics. This book is further energized by discussions of how neurotransmitter deficits, neuro-inflammation, and oxidative stress impair neuronal plasticity and contribute to Alzheimer's neurodegeneration. The diversity of topics presented in just the right depth will interest clinicians and researchers alike. This book inspires confidence that effective treatments could be developed based upon the expanding list of potential therapeutic targets.

\title{
How to reference
}

In order to correctly reference this scholarly work, feel free to copy and paste the following:

Emel Koseoglu (2011). The Relations Between the Vitamins and Alzheimer Dementia, Alzheimer's Disease Pathogenesis-Core Concepts, Shifting Paradigms and Therapeutic Targets, Dr. Suzanne De La Monte (Ed.), ISBN: 978-953-307-690-4, InTech, Available from: http://www.intechopen.com/books/alzheimer-s-diseasepathogenesis-core-concepts-shifting-paradigms-and-therapeutic-targets/the-relations-between-the-vitaminsand-alzheimer-dementia

\section{INTECH}

open science | open minds

\section{InTech Europe}

University Campus STeP Ri

Slavka Krautzeka 83/A

51000 Rijeka, Croatia

Phone: +385 (51) 770447

Fax: +385 (51) 686166

www.intechopen.com

\section{InTech China}

Unit 405, Office Block, Hotel Equatorial Shanghai

No.65, Yan An Road (West), Shanghai, 200040, China 中国上海市延安西路65号上海国际贵都大饭店办公楼 405 单元

Phone: +86-21-62489820

Fax: +86-21-62489821 
(C) 2011 The Author(s). Licensee IntechOpen. This chapter is distributed under the terms of the Creative Commons Attribution-NonCommercialShareAlike-3.0 License, which permits use, distribution and reproduction for non-commercial purposes, provided the original is properly cited and derivative works building on this content are distributed under the same license. 